\section{ECONOMICS}

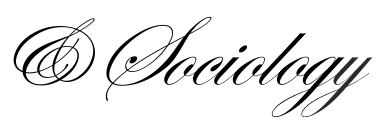

\title{
WHY DOES UKRAINIAN ECONOMY GROW SO SLOWLY?
}

\author{
Viktoriya A. Palekhova \\ Petro Mobyla Black Sea National \\ University, \\ Ukraine \\ E-mail: \\ vik.toria.palehova@,chmnu.edu.ua \\ ORCID 0000-0002-8481-6669
}

Received: March, 2020

1st Revision: December 2020

Accepted: February, 2021

DOI: $10.14254 / 2071-$

789X.2021/14-1/2
ABSTRACT. Economic growth is an indicator that synthesizes the effects of numerous factors and impulses. This article aims to highlight from a wide range of factors, those with the highest priority and correlate them with Ukrainian realities. The existing approaches to the analysis of economic growth are overviewed. The drivers of economic growth named among "the 10 rules of successful nations" by R. Sharma (2020) are investigated in detail. Each rule is considered in detail, taking into account other economists' opinions and the recent global trends. We use Ukrainian and Polish data to check how each of those rules applies. On the one hand, this study demonstrates the relevance of the proposed rules. Also, it explains both successes of Polish economy and the failures of Ukrainian one. Polish economy does not comply with only one of the development rules suggested by Sharma (2020) - the demographic one (however, the corrective measures are already being taken). At the same time, Ukrainian economy does not comply with the absolute majority of those rules. Even when problems in Ukraine are in line with global trends, they take the worst shape (populistdemagogues, bad billionaires, bad investments, etc.). The analysis helps with structuring the factors (migration is a multidimensional problem with many negative symptoms) and identifying the second-order problems (the volatility of many indicators that may indicate inconsistency in the implementation of reforms). The issues revealed in this article can be considered as a roadmap for necessary transformations.

JEL Classification: O41, O47, O52, P52

Keywords: economic growth, growth rate, determinants of economics growth, Ukrainian economy.

\section{Introduction}

Despite the long history of theoretical and empirical research, the issue of economic growth still remains relevant. In explaining their choice, researchers often refer to the testimony by the Nobel laureate Robert Lucas: "Once you start thinking about growth, it's hard to think about anything else" (1988). However, the urgency of these issues is more obvious for developing countries, and, above all, the search for the driving forces of economic growth: to identify them means to gain the ability to manage further development. 
The first 24 years of Ukraine's independence are almost equally split in half into the years of economic recession and those of recovery. In the last four years of the most recent national history the economy at last has demonstrated long-awaited growth. But its rates are extremely modest, around 3\% (Graph 1). Such fluctuations are not noticeable to the majority of the population due to the low base rate.

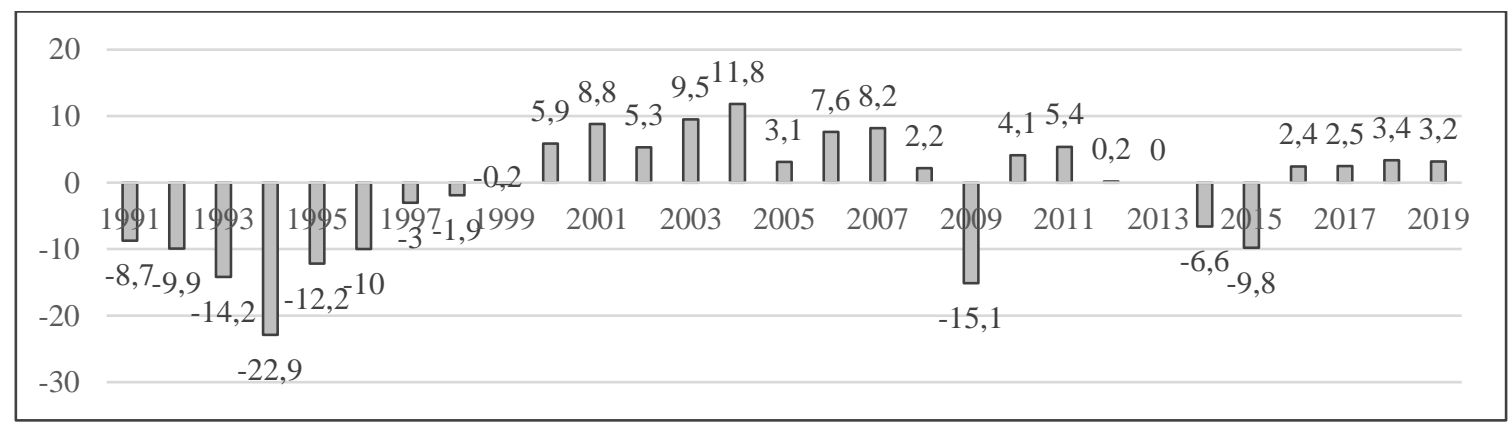

Graph 1. Ukraine GDP growth rate, \%

Source: author's presentation. Data source: The State Statistics Service of Ukraine

According to the IMF, in 2016-2019 the global economy has been growing in the range from $2,9 \%$ to $3,8 \%$. Emerging markets and developing economies have traditionally shown higher rates. Thus, even if Ukraine demonstrates growth, it still keeps lagging behind other countries. Ukrainian economists talk about the formation of "a lagging growth model", as a result of which national production loses its former market advantages (Skripnichenko, 2018). And the World Bank, specifying its forecasts, reduced the previously announced growth forecast for Ukraine.

The trajectory of Ukrainian economy looks especially gloomy against the successful transformation of other post-socialist countries. Ukrainian reformers have traditionally appealed to Polish experience, arguing countries' territorial and ideological similarity, common history, etc. But we can only see a widening gap between these two economies (Graph 2). It is noteworthy that in order to achieve this result, it was enough for Polish economy to grow at a moderate pace: in only nine of the last 29 years its growth exceeded $5 \%$. But the process of growth was still constant, and its dynamism stood out relative to other EU countries.

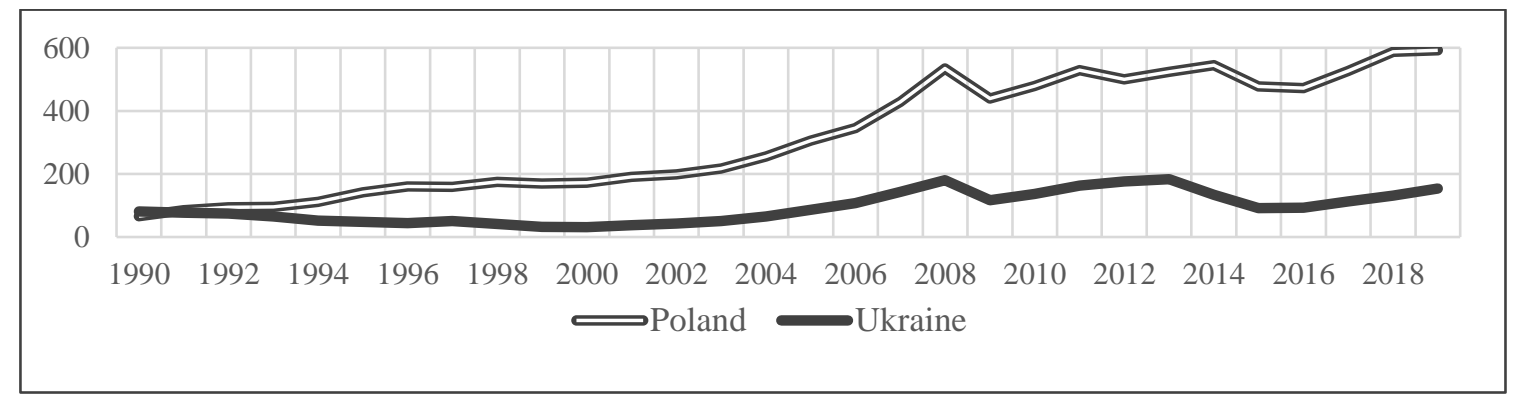

Graph 2. Ukraine and Poland GDP (current US\$, billion)

Source: author's presentation. Data source: The World Bank.

The dynamics of Ukrainian GDP, despite its population decline, turned the country into the poorest country in Europe (in terms of GDP per capita). In this paper we investigate the reasons that prevent such a large country, by European standards, with a significant economic potential and productive population from growing faster and solving many important economic and social problems (raising living standards, new jobs creation, human capital development, etc.). 


\section{Literature review}

The 1980s and 1990s were dominated by the idea that liberal economic policies, such as privatization, deregulation, and reducing the role of government, were needed to accelerate economic growth in developing countries. However, many countries have achieved varying results by implementing market reforms, reducing budget deficits, reducing restrictions on international trade and capital flows, and narrowing the public sector. In some areas they exceeded even the optimistic expectations, but for most of the republics of the former USSR in the 1990s there was an unprecedented scale of economic downturn, especially for Ukraine (in which reforms were extremely inconsistent).

Summing up the decade of reforms, the World Bank (2005) had to admit that such contradictory results led to the conclusion that the most important lesson from the experience of the 1990s was the realization of the exceptional incompleteness of ideas about economic growth. Experience has shown that there is no one-fit-all set of development rules.

Based on this, Hausmann, Rodrik, and Velasco (2005) proposed a change in approach: instead of insisting on universal recipes, they proposed to help countries diagnose the main obstacles to economic growth. It is on these constraints that we should focus our reforms instead of trying to solve all the problems at once.

In 2008, the Commission on Growth and Development, headed by Nobel Laureate Michael Spence, produced The Growth Report: Strategies for Sustained Growth and Inclusive Development. This report was an attempted to reveal the successful experiences of growth of the world's most dynamic economies - to summarize the development strategies of 13 countries, which showed growth of an average of $7 \%$ for 25 years or more (a generation). Among the common factors that promoted growth was the use of the benefits of globalization, greater openness of the national economies, their integration into the world. Other necessary conditions included: macroeconomic stability, a high share of investment in GDP $(25 \%$ and above), purposeful and efficient government, among the priorities of which were ensuring competition, universal access to health and education.

Economic growth is affected by many factors (see for example Barro (1991) for a thorough review of these factors). The IMF and the World Bank take into account dozens or even hundreds of indicators when forecasting growth rates.

It is quite natural that many empirical studies are limited to assessing the impact on GDP dynamics of one variable, gradually delving into the analysis of smaller details. But the variety of factors that determine economic growth and the tendency of economists to exaggerate the importance of some of them suggest the importance of their comprehensive analysis. For example, the rich experience of Greece allows us not only to conduct empirical studies of the impact of public debt on GDP but also investigate other factors such as investment, private and government consumption, trade openness, and population growth (Pegkas, 2018).

Boldeanu and Constantinescu (2015) do offer any empirical analysis in their analysis. Among the main determinants affecting economic growth they suggest public expenditure, trade components and FDI, and other non-economic factors. Without doubt the latter group of factors is the most numerous and it includes corruption, political factors like political regimes, political instability, civil freedom, socio-cultural factors (ethnic diversity and fragmentation, language, religion, civic norms), geography (soil quality, natural resources, climate topography of a region or state).

Simionescu et al. (2017b) analyze determinants of economic growth using the example of five countries (Czech and Slovak Republics, Hungary, Poland and Romania) during the 2003-2016. For meaningful comparison they study the effect of inflation rate, employment rate, FDI inflows, work force with education, government expenditure on education, on R\&D. 
The high growth rates of the Indian economy in recent decades have created a rich empirical basis for summarizing the growth experience. Biswas and Saha (2014) assessed the impact of gross domestic capital formation, employment, export, FDI, money supply, inflation and fiscal deficit on economic growth during 1980-2010. A wide range of macroeconomic factors that determine India's economic growth have also been explored by Sharma, Kautish and Kumar (2018). They analyzed the short- and long-term impact of foreign aid, government expenditure, FDI, trade openness, exchange rate, human capital, and inflation. Das (2020) analyzes the relationship between the dynamics of real GDP and a set of following variables: FDI inflows, gross fixed capital formation, GDP deflator, trade openness and real effective exchange rate from 1996 to 2018.

Ukraine periodicals abound in articles published in the process of the scientific discussion on existing problems with gloomy forecasts for the future prospects for socio-economic development of the country. O. Bazhenova, V. Heyets, S. Korablin, I. Kryuchkova, V. Onushchenko, S. Shumska, M. Skripnichenko, V. Tarasevych, Y. Zhalilo and others made a significant contribution to the development of this issue. Current trends, factors of economic growth in Ukraine and obstacles to its development are actively discussed on the pages of scientific journals. However, diagnosing the correspondence of domestic realities to the recognized and widespread indicators of economic growth remains an important problem. The article proposes to limit ourselves to only ten of them.

\section{Methodological approach}

After analyzing a wide range of indicators that affect the growth rate of emerging economies, the most common ones were selected. The vast majority of them are collected in "The 10 Rules of Successful Nations" (2020), the international bestseller by Ruchir Sharma, the chief global strategist at Morgan Stanley Investment Management. The 2020 publication is a summary of a more detailed study published in 2016. His first book on economic growth (2012) represents an analysis of the existing combinations of economic and political forces and the subsequent diagnosis of the economy's ability to grow. Ukraine is given almost no attention and it is only briefly mentioned in his first book and is not found among the large number of eloquent examples (if we do not consider the mentioning of the aggression by Russia).

At the same time, Sharma does not use the "cookie-cutter approach to policy", providing recommendations for economic growth policy. Despite the popular-science nature of his work, they are the result of a 25-year study of the drivers of economic development, spanning the experience of 56 developing countries that have managed to sustain economic growth of more than $6 \%$ for at least a decade (much more countries than in the report prepared by the Commission on Growth and Development, which showed a slightly slower pace over a shorter period of time). The proposed rules include both economic and non-economic factors (for example political factors like a bright leader-reformer and right-wing populism, geographic factors like taking advantage of location, and other factors like no hype in the media). All of them have been repeatedly tested in practice and allow us to determine the probability of growth in the next $5-10$ years.

Therefore, this article aims to analyze the proposed set of rules, assess how successful of an attempt it is to systematize growth factors, and in parallel to check the extent to which Ukraine complies with these rules compared to other countries, especially Poland. In addition, it diagnoses the main problems that hinder Ukrainian economic growth.

Consideration of each of the ten rules involves the use of theoretical and statistical analysis. In analyzing the proposed indicators, the views of other economists, current trends in other countries are taken into account. In our analysis we use the statistical data published by the World Bank, the International Monetary Fund, the State Statistics Service of Ukraine, the 
National Bank of Ukraine, and Forbes. The choice of the period under consideration is determined in each case by appropriateness and availability of data. Where possible, the entire period of Ukraine's independence is considered, in other cases the data is available since the late 1990s, for example the rate of inflation - since the monetary reform (1996), including the latest available data.

\section{Conducting research and results}

To what extent does Ukraine comply with the ten rules formulated by Sharma? The first rule is demographic. After all, among the many determinants of economic growth the quantity and quality of resources, especially labor plays important role. Countries where the share of people of working age is growing faster than other groups receive so-called "demographic dividends" in the form of accelerated economic growth. Accordingly, the reduction of active labor resources significantly slows it down. Sharma refers to statistics, which convincingly testifies to the fact that since 1960 there have been only a few cases when, despite the decline of the population, the economy has been steadily growing at a rate of at least $6 \%$.

It is very significant that the famous American economist Gordon (2014) called demographic processes the first of four headwinds that impede future U.S. economic growth.

The reduction of the active population affects the economy not only from the side of the aggregate supply (reducing the available resources), but also seriously reflects on the aggregate demand side, reducing it and changing its structure. Thus, the aging of the population is a global problem of the humankind, a much more pressing one of the developed counties. Such transformation of the economy in connection with natural changes in priorities and behavioral patterns was called "silver economy" or "longevity economy". But for Ukraine the problem is much more acute: the population has been constantly shrinking since 1994 (Graph 3).

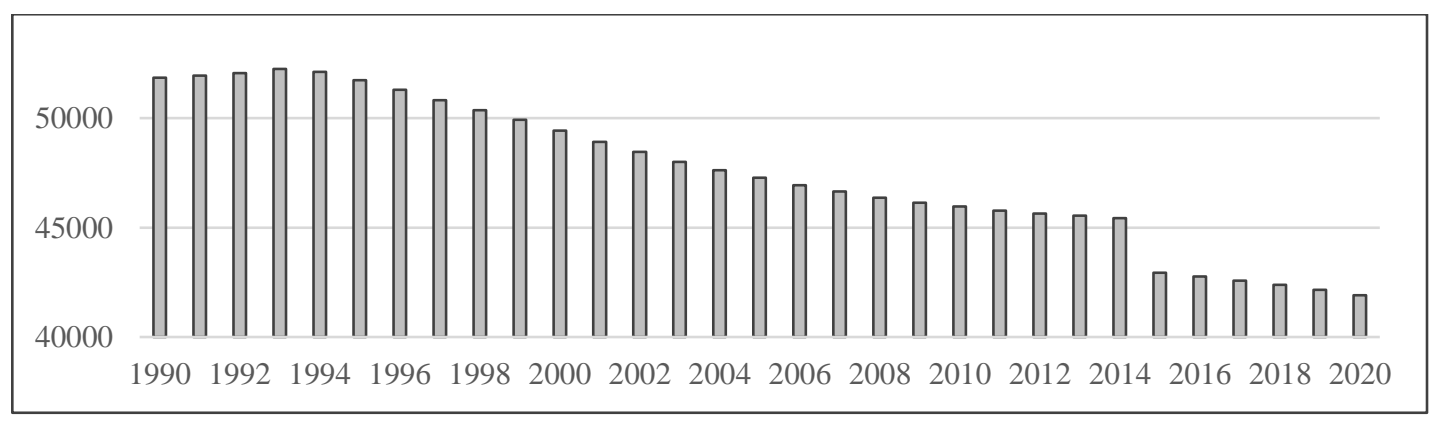

Graph 3. Total present population of Ukraine, as of 1 January; thsd

(from 2014 excluding the temporarily occupied territories of the Autonomous Republic of Crimea, and the city of Sevastopol)

Source: author's calculations. Data source: The State Statistics Service of the Ukraine

According to the UN population forecast, Ukraine is among the top ten countries in the world whose population will decline by more than $15 \%$ by 2050 (United Nations, 2020). However, nine out of ten countries in that list (except Japan) are in Central and Eastern Europe. In addition to Bulgaria, which ranks first, Latvia, Lithuania, the Republic of Moldova, Romania, Hungary, and Balkan countries are rapidly losing their citizens. Despite all the spectrum of specific reasons in each case, there are general geopolitical reasons: the collapse of the Soviet Union and the enlargement of the European Union (Grant, 2019).

Similarly, in Ukraine the impact of migration is added to the low birth rate and high mortality rate, which has increased significantly since 2014. Sociologists state that Ukrainians 
perceive external migration (especially educational migration for their children) as a reliable social elevator that allows and significantly improve living standards (Libanova, 2019). Due to the deterioration of relations with Russia, Poland has become the dominant destination for labour migration. The high growth rate of its economy has become an additional reason for mass employment of Ukrainian workers.

Studies show that the loss of human capital due to the emigration of Poles to Great Britain had a negative impact on Poland's economic growth in 2004-2015 (Simionescu et al., 2017a). In 2019, in order to reduce the outflow of young professionals abroad, the personal income tax for employees under 26 years of age was abolished. Poland's population is also aging and declining since 2000, but at a much slower pace. And it is quite reasonable for Poland to count on a regular influx of Ukrainian labor rather than hope for the return of compatriots from Great Britain as a result of Brexit.

As for Ukraine, there is every reason to believe that the rate of population decline is actually faster than the State Statistics Service indicates (the last population census was in 2001, and surveys on emigration of labor force are done every five years). According to the alternative calculations (Ptoukha Institute for Demography and Social Studies of the National Academy of Sciences of Ukraine, Ukrainian Institute for the Future), back in 2017 the population of Ukraine, excluding the temporarily occupied territory, was 36 million people (less than that of Poland). Half of them were economically inactive, and almost 12 million were pensioners. If the rate of depopulation and aging of the population continues, by 2030, 8 million workers will account for twice as many retirees (Ukrainian Institute for the Future, 2017).

However, today Ukrainian entrepreneurs name the factors that impede output growth the most important factor that causes the qualified staff shortage (National Bank of Ukraine, 2020). The paradox is that the fundamental reason for the acceleration of migration flows and reduced reproduction of the population is the current macroeconomic situation, and for a breakthrough it is necessary to have long-term and tangible economic growth at the household level. This is confirmed by previous studies in Central and Eastern Europe, including Ukraine (Simionescu et al., 2016). The more the country lags behind the advanced countries in development, the larger the outflow of human capital, the less sense it makes for intellectuals and innovators to stay in the country.

According to the second rule of Sharma, for significant progressive changes in the national economy we need an authoritative leader, large-scale support and a clear public awareness of the need for painful reforms. The examples traditionally cited are M. Thatcher, R. Reagan, D. Xiaoping, Lee Kuan Yew. Leszek Balcerowicz is rightfully considered the "Ludwig Erhard of Polish reforms".

However, the recent election campaigns in Ukraine, as well as the choice of the majority of citizens, stubbornly demonstrated the unfading strength of populist sentiment. Thus, promises to raise salaries by an order of magnitude, to reduce the price of gas by half or even four times, have always found their admirers. Aging of the population is also altering the structure of the electorate. As the share of elderly people, who mostly vote for socialist slogans, increases, so dues the number of populists in power.

We have to admit that populism can be considered a global trend during the presidency of Trump, Bolsonaro, Duterte, successful Brexit, victory in the parliamentary elections in Italy Five Star Movement and the Northern League, success of the parties Podemos in Spain, Syriza in Greece and other well-known events. In 2019, the spread of populist sentiment in Europe was seen as one of the possible triggers of a global crisis. At the request of the Guardian, a team of scientists called "Team Populism" studied populist discourse in speeches by almost 140 world leaders from 40 countries over 20 years, and noted that the number of populist leaders has more than doubled since the beginning of the 21 st century. (Lewis et al., 2019). 
Dornbusch and Edwards in 1989 gave a classical definition of populism, describing it on the basis of the rich experience of Latin American countries and emphasizing its focus on growth and income redistribution and disregard for the risks of inflation and deficit finance, underestimating "the reaction of economic agents to aggressive non-market policies". The tragedy of today's Venezuela can serve as a good example of what the passion for redistribution can lead to. After 30 years Edwards had to distinguish between "classical populism" and "new populism", and at the same time recognize the preservation of the traits of the traditional populism in numerous modern manifestations (Edwards, 2019).

However, Sharma opposes "populist-demagogues versus populists who get it", just as Rodrik calls not to mix political and economic populism, because they are not always adjacent (Rodrik, 2018). Economic populism is, in his opinion, a quiet natural reaction to the decline in trust in power and living standards. It is sometimes necessary because it is aimed at sources of economic inequality (for example, in the U.S. after Great Recession it has taken the form of a reduction in the financial sector).

But it is difficult to draw parallels between the New Course proposed by Y. Tymoshenko in 2019 and initiatives of President F.D. Roosevelt during the New Deal launched in 1932, which Rodrik cites as an example, "when economic populism works" (Rodrik, 2018). It is much easier to put together Trump's contemptuous remarks about the Federal Reserve, Erdogan's criticism of the central bank, and political pressure on the National Bank of Ukraine that led to its chairman's resignation in the summer of 2020.

The state of the economy and the phase of the economic cycle are also important. Selfsatisfaction and stagnation, which are fraught with years of growth, clearly do not threaten Ukraine. But the post-revolutionary readiness of the people to tolerate deprivation for the sake of a bright goal was not used again. The latest crisis dates back to 2014-2015. After its passage, the economy was growing so sluggishly and anemically that the absolute majority of citizens simply do not feel the growth. The conquests of the Ukrainian revolution have not been used properly not for the first time, and hopes have simply been deceived.

Returning to the definition of populism by Dornbusch\& Edwards, it should be agreed that politicians will have more opportunities to come to power if they focus on redistribution, the greater the income gap. The third rule concerns actually inequality in income distribution. Sharma believes that low level of inequality contributes to long and constant economic growth, and high or sharply increasing level can interrupt such growth.

In 1954 Kuznets came to the conclusion that with the growth of income per capita, the inequality of its distribution first increases, then decreases (known as "Kuznets curve"). Later on, the relationship did not look so obvious. Piketty (2014) proved that economic inequality deepened during the XIX-XX centuries, with the exception of the period of 1914-1980.

Recent studies show that economic growth can be accompanied by an increase, decrease, and preservation of social inequality. Economic growth is a necessary but not sufficient condition for poverty reduction - it is not so much the rate of growth as the quality of growth that is important. It is in this context that the concepts of broad-based growth, shared growth, inclusive growth, pro-poor growth (Ravallion \& Chen, 2003) have been introduced. It is known that in advanced countries inequality is reduced not so much for economic reasons as because society consciously chooses to reduce inequality as it becomes richer.

How does the degree of uniformity affect the rate of economic growth? The Gini index, which shows the degree of deviation from the perfectly even distribution of income in society, is updated in the World Bank database on an irregular basis and is not available for all countries. Maybe that's why Sharma carefully studies the ratings of Forbes' billionaires, not only to determine the degree of inequality, but also to assess the likelihood that it will cause discontent of citizens and delay economic growth, as it can have a significant impact on political reaction and economic policy. 
Therefore, he separates "good billionaires" and "bad billionaires". The latter earn money in so-called rent seeking industries, which are associated with corruption (mining, construction, real estate management, stock exchange speculation). Contrary to them, it is possible to become "good billionaires" by dealing with real competition in the industrial sectors, using their innovative skills, without wasting time on attempts to secure ownership of limited resources and the right to receive the maximum possible rent from them. "Good" industries include manufacturing, high-tech, pharmaceuticals, trade and entertainment. The corresponding indicators are shown in the Table 1.

Table 1. Billionaire Wealth in Some Emerging Market Economies (2020)

\begin{tabular}{lccc} 
Country & $\begin{array}{c}\text { Total billionaire } \\
\text { wealth/GDP, } \%\end{array}$ & $\begin{array}{c}\text { Bad billionaires' wealth/total } \\
\text { billionaire wealth, } \%\end{array}$ & $\begin{array}{c}\text { Inherited billionaires' } \\
\text { wealth/total billionaire } \\
\text { wealth, \% }\end{array}$ \\
\hline Brazil & 6,88 & 44,30 & 47,13 \\
\hline China & 8,49 & 20,35 & 2,51 \\
\hline Georgia & 30,15 & 100 & 0 \\
\hline Poland & 2,26 & 52,34 & 0 \\
\hline Russia & 23,44 & 70,91 & 0 \\
\hline Turkey & 5,23 & 51,16 & 0 \\
\hline Ukraine & 5,32 & 100 & 18,44 \\
\hline EM Average & 8,03 & 58,17 & \\
\hline
\end{tabular}

Source: author's calculations. Data source: The Forbes, 2020, March

In Ukraine, as well as in Russia, a new class of oligarchs was created in the course of market transformations. A good sign of this can only be considered the absence of inherited property. However, this is due only to a short period during which the first generation of billionaires simply did not have time to pass their property to the next generation.

Economic growth is possible if oligarchs do not control a significant part of the wealth. It is known that with the increase in income the marginal propensity to consume decreases, which inevitably slows down the growth of total consumer spending. Inequalities affect economic growth also indirectly through corruption, shadow economy, tax evasion, and redistributive processes in the form of social security programs.

If the total wealth of billionaires is more than $10 \%$ of GDP, Sharma treated it as a bad sign. In Ukraine, this figure has grown steadily in recent years and reached 12\% in 2019 (in 2020 due to a decrease in both the number of billionaires and their wealth, the percentage decreased significantly). It is significantly higher than in Poland, and of these countries it is second only to Russia.

The situation is further complicated by the fact that all $100 \%$ of Ukrainian billionaires have become rich by running their businesses in rent-seeking industries. In addition, they control most of the media and politics. Therefore, they have all the incentives to oppose creative destruction, and therefore high rates of economic growth.

The fourth rule states that the most important factor for success is a moderate government intervention in the economy. Saving the economy from the Great Recession, many countries were forced to return to Keynesian recipes and resort to expansionary fiscal policy. The pandemic has led to another significant strengthening of the role of the state. Therefore, the issue of necessary and excessive government spending does not lose its relevance.

It is well known that the government, at least, should be able to solve the problems of "market failure". In addition, in difficult crisis situations, it has to assume the role of "lender of last resort". But the second half of the twentieth century was marked by the formation of the 
so-called "welfare state" in advanced countries, when the emphasis was on financing pensions, health care and education.

In post-socialist countries the yearning for paternalism seems to be inexorable. Alesina \& Fuchs-Schündeln (2007) examined the attitudes of state intervention in the economic life of West and East Germans and concluded that it takes 20-40 years to close the existing differences of opinion. The majority of Ukrainian people were very reluctant to part with socialism. At the same time, the authorities did not dare to carry out decisive liberal reforms, rightly fearing the lack of political support. The choice was made in favor of gradual transformation, preservation of numerous social priorities, provision of benefits to producers, soft budget and monetary policy. During the 1990s, this trend was called "Ukrainianization of the economy" outside the country (Kubicek, 1999).

To this day there are still many examples of excessive government intervention and inefficient government spending. Commission on Growth and Development (2008) named subsidizing energy number one in the list of bad policies. Sharma considers one of the common methods of preventing high inflation through government regulation of prices - the establishment of government-owned energy companies. But as a result of their activities, there is a noticeable reduction in investment in such undervalued sectors of the economy, and underpricing provokes excessive wasteful consumption (which generates a deficit that accelerates inflation). Investment in infrastructure contributes much more to economic growth than any free distribution of benefits.

The government needs to have adequate revenues to finance its expenditures. Over time, the tax burden on business in Ukraine has decreased, albeit inconsistently. Although, analyzing the data of the World Bank, which does not include social contributions and contributions to the pension fund, we can see that the domestic-tax-revenue-to-GDP ratio has been growing, gradually approaching the level of the EU countries with the highest social standards in the world, but at the same time with the budget deficits and public debt (Graph 4). The upward trend of that indicator for Ukraine contrasts significantly with fluctuations in a certain range for other countries, and relative to that of Poland loses the once existing advantages.

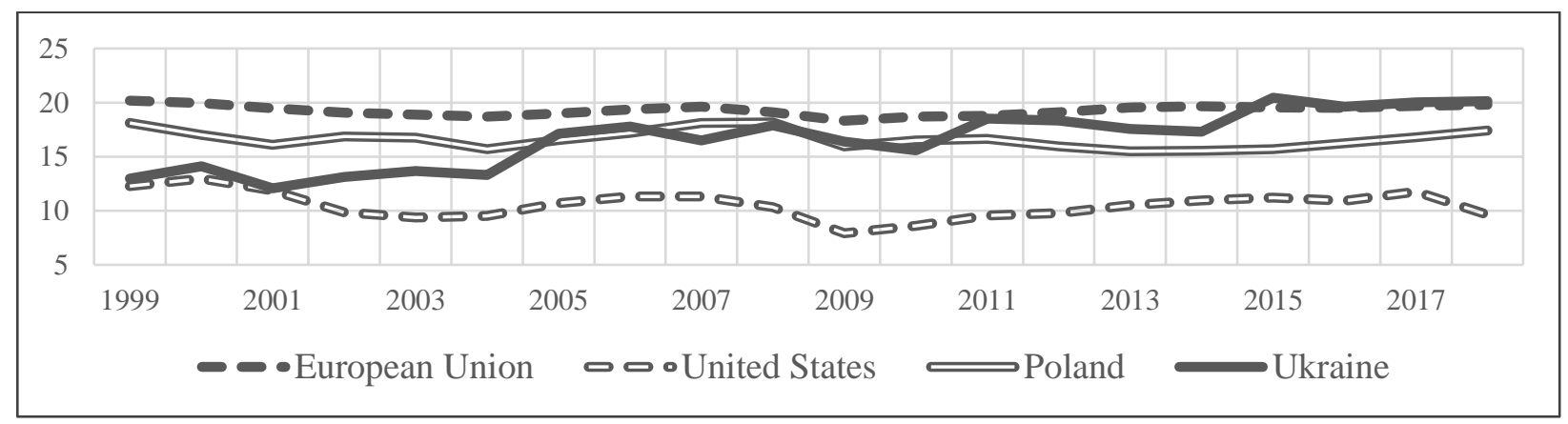

Graph 4. Tax revenue (\% of GDP)

Source: author's calculations. Data source: The World Bank

The size of the public sector of Ukraine clearly indicates that in the twenty-ninth year of reforms, the privatization of inefficient state-owned enterprises, banks (the share of which in the total of all banks is 54\%) and strict discipline in the use of public funds remain relevant.

Sharma stresses (especially for supporters of the Chinese path of development) how China's success is due to market reforms, in which the country has lost most of its socialist qualities. Medicine has become paid. The government has freed itself from the worries about the education and employment of second and subsequent children, and pensions.

However, it is impossible not to take into account the development trends of postindustrial countries, their major changes in the scope and forms of government intervention in 
the economy. The structure of budget expenditures should change in favor of human capital development. At the same time, they are being reduced due to, if not the complete exit of the government from certain areas, then the development of new forms of public-private partnership. The COVID-19 pandemic has significantly raised the issue of health care financing. If before it was perceived as an expenditure item and even in the Soviet times it was carried out on a residual basis, now it should be seen as an investment that can accelerate economic growth in the long run.

According to the fifth rule, a country should use its geographical location to its advantage for economic growth. Sharma gives the example of transformation of Dubai from an ordinary little-known emirate to the world's largest trade center is given. It is appropriate to recall the well-known flying geese paradigm and its application to East Asian regional development. First, second and third tier countries consistently provide economic and technological support. By taking their place in a certain "economic order", national economies help to accelerate both their growth and that of the region as a whole.

Ukraine, despite the favorable location at the crossroads between Europe and Asia, is unlucky to have such large neighbor. Therefore, it is not possible to use the advantages of its disposition, like Poland, Mexico, Vietnam or Bangladesh. Rather, the geographical and historical ties with Russia not only provoke military and political conflicts, but also have a negative impact on the national economy of Ukraine. (In the previous book of Sharma (2012), Ukraine is remembered only to illustrate the inappropriateness of copying the Russian strategy, in particular, the functioning of the stock market. The remark is quite correct, as today only a few of the ten existing exchanges operate, whose activities are mainly focused on trading in government bonds).

The fifth rule also concerns the distribution of the population within the country. It is not normal for the majority of the population to live in the capital. In that case the rest of the country suffers, and it is fraught with general stagnation. Sharma deduces the rule "three-toone": the population of the largest city of the country should not exceed the population of the next largest city by more than three times.

According to the data of the State Statistics Service of Ukraine, at the beginning of 2020 there were 2.967 million people officially living in Kyiv, and in the second-largest Ukrainian city of Kharkiv - 1.443 million (half as many). The numbers doubtfully reflect the reality due to a large number of unaccounted for citizens. However, this pertains to both cities.

The sixth rule can be called the most predictable and even trivial. Investments are a recognized engine of economic growth. They determine not only the long-term trend, but also the fluctuations of GDP during the business cycle. Investments themselves are very volatile due to a huge number of factors that affect them directly and indirectly.

Investment share of GDP has traditionally been an important criterion in predicting future development. Sharma points out that the chances of economic growth increase significantly if this share is $25-35 \%$. If it is less than $20 \%$, the probability of growth drops. And for countries claiming the title of economic miracle, the values are sometimes over the top. Thus, since 2003, the share of investments in China has not fallen below $40 \%$ (which, according to Sharma, borders on an already excessive and senseless level).

In Ukraine, the share of investments in GDP in the XXI century did not exceed 28\%, and in 2014 and 2019 fell to its lowest marks. In comparison to the value of the indicator for Poland we once more have to state the larger volatility of the Ukrainian one (Graph 5). 


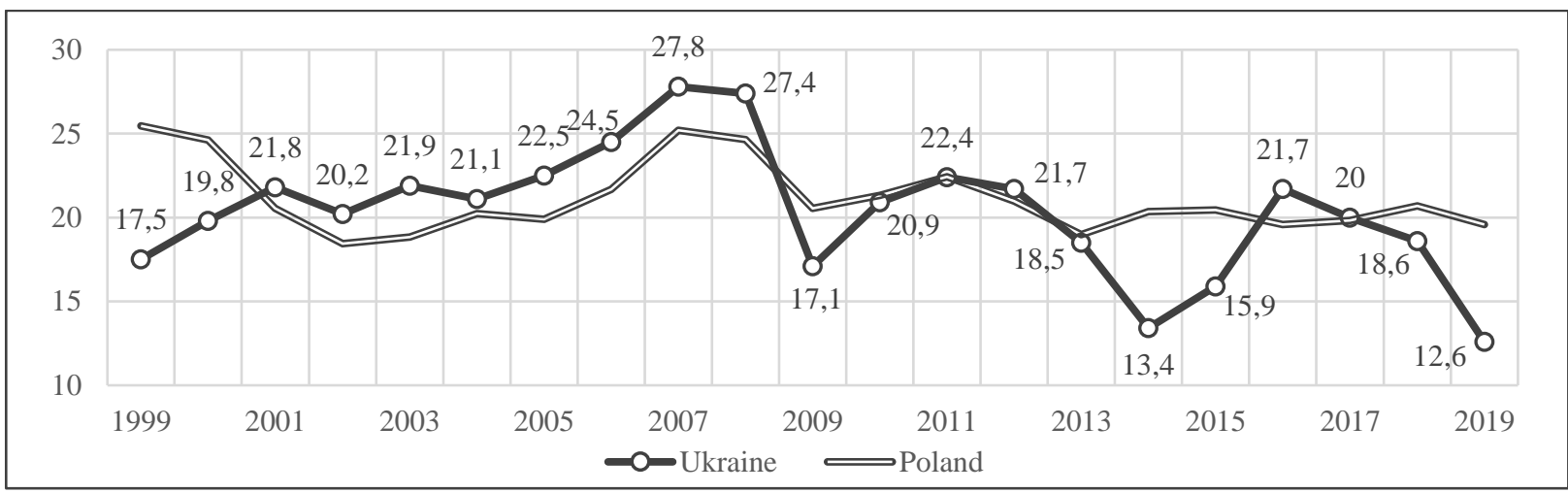

Graph 5. Gross capital formation (\% of GDP)

Source: author's calculations. Data source: The World Bank

The decline in investment activity over the past three years makes economic growth impossible not only in the medium term, but also for the stable functioning of the infrastructure sectors. The prospects of the further growth of investment are rather problematic due to the fact that the main source of their financing has been and still is their own funds, and the possibility of borrowing is limited by the high cost of credit. The share of loans among other sources of financing is at the level of 7-8\%, and the participation of foreign investors is simply negligible.

A more in-depth analysis proposed by Sharma, apart from quantitative characteristics, is not in favor of Ukraine; in other words, it is necessary to take into consideration qualitative characteristics, i.e., to monitor where the money is going. Good investment implies investments in inventions, new technologies, production and infrastructure. Bad investments (as in our case) are directed to real estate and raw materials industries. Thus, it is proposed to evaluate investments by what they result in, by the return in the form of productivity growth, multiplier and accelerator, which allow to give the national economy stable growth rates.

Rule seven, unlike the previous rule, is more controversial. Although the author has the most stringent requirements here: in his opinion, "high inflation is always a bad sign, and low inflation is often good". High inflation is understood as a rise in consumer prices above $6 \%$ for developing economies and about $2 \%$ for advanced economies. High inflation, by reducing the value of money, makes savings meaningless, reduces the amount of funds available for investment, and is generally more volatile. As an example, Sharma compares Brazil and China. In Brazil, inflation is becoming a problem already with $4 \%$ economic growth. In China, even double-digit growth rates were accompanied by inflation not exceeding 5\% (it can be supposed that this happened largely due to investments that affect not only aggregate demand, but also aggregate supply, curbing inflation).

However, one cannot help noticing the existence of another viewpoint, according to which too low inflation does more harm than benefit. This is the conclusion reached by Barro (1995). Krugman (2012) argued that the goal of stabilization policy should be core inflation at $4 \%$, citing the IMF paper "Rethinking Macroeconomic Police" (Blanchard et al., 2010). The Great Recession forced the IMF experts to revise their estimates of the desired inflation, which implemented a theoretical liquidity trap scheme in practice, leaving no room for maneuver for central banks.

Ukrainian economists have also come to their own conclusions about the optimal inflation rate. Thus, Galchinsky, Heyets, Korablin called higher inflation rates acceptable for Ukraine. At the same time, they proceeded from our own history of a short period of high growth rates in 2000-2007 (average annual GDP growth rate of 7.5\%), which was accompanied by rather high inflation (Graph 6). 


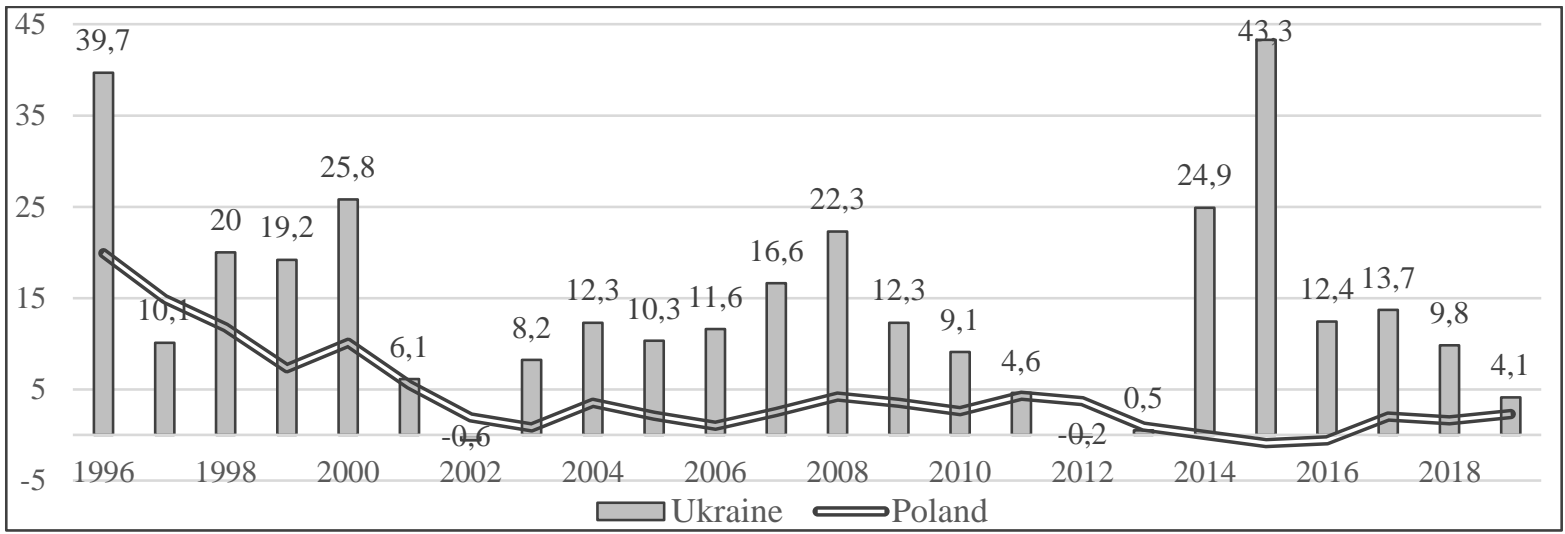

Graph 6. Inflation rate, \%

Source: author's calculations. Data source: The State Statistics Service of Ukraine and The Statistics Poland

Comparing the dynamics of price levels in Ukraine and Poland makes us to take into account the impact on of the inflation volatility on economic growth. Like any uncertainty, it prevents economic agents from making optimal decisions. The negative impact of excessive consumer price volatility on economic growth has been demonstrated in Neanidis and Savva (2013). After analyzing data for 182 countries, Jha and Dang (2012) concluded that if inflation exceeds $10 \%$, volatility has a significant negative effect on growth. However, when analyzing the price dynamics in Ukraine after 1996, it is necessary to recognize as quite reasonable the arguments of Sharma, which concern the reaction of the central bank to the inflation rate above the target range. Even if inflation accompanies economic growth, the latter will not be able to continue for a long time, as sooner or later the central bank will have to tighten monetary policy to suppress inflation.

This happened in Ukraine, when the National Bank, fearing inflation, raised the discount rate, causing further appreciation of already expensive loans. After a temporary decline since mid-2017, the bank has been able to increase the interest rate on its loans since the middle of 2017. The NBU returned to tight monetary policy and raised the discount rate for almost two years (to 18\%). In this way, the central bank is forcing commercial banks to raise interest rates on loans. This reduces the role of commercial lending in the economic development of the country, thus curbing the growth of the overall price level. The worst case is undoubtedly the combination of high inflation and anemic economic growth.

Only in April 2019, the NBU began to reduce the rate, bringing it to historically lowest level of $6 \%$ and forming a new trend of easing monetary policy. But credit resources remain expensive for many sectors of the economy with insufficient profitability. Ukraine's experience shows that low inflation does not guarantee economic growth and lower unemployment. And do we need inflation of $5 \%$ along with the GDP growth of 2-3\%?

At first glance, the eighth rule finally corresponds to the Ukrainian economy: economic growth is promoted by cheap currency. According to the Big Mac index, the Ukrainian currency is one of the most undervalued. Cheap currency should cause the inflow of money into the country through exports, tourism, remittances by migrant workers.

But the optimism runs out as soon as it's born. First of all, the rule also contains a qualification: an inexpensive currency functions in a stable financial environment with low inflation expectations. This combination creates a feeling of reliability for producers, bankers and investors. Secondly, Sharma asks the question: Does money flow into or out of the country? Money flows across borders are analyzed with the help of the balance of payments. As it follows from Graph 7, the economic growth of 2000-2005 looks quite obvious and the growth of the last years seem quite problematic. Devaluation alone does not guarantee prosperity. 


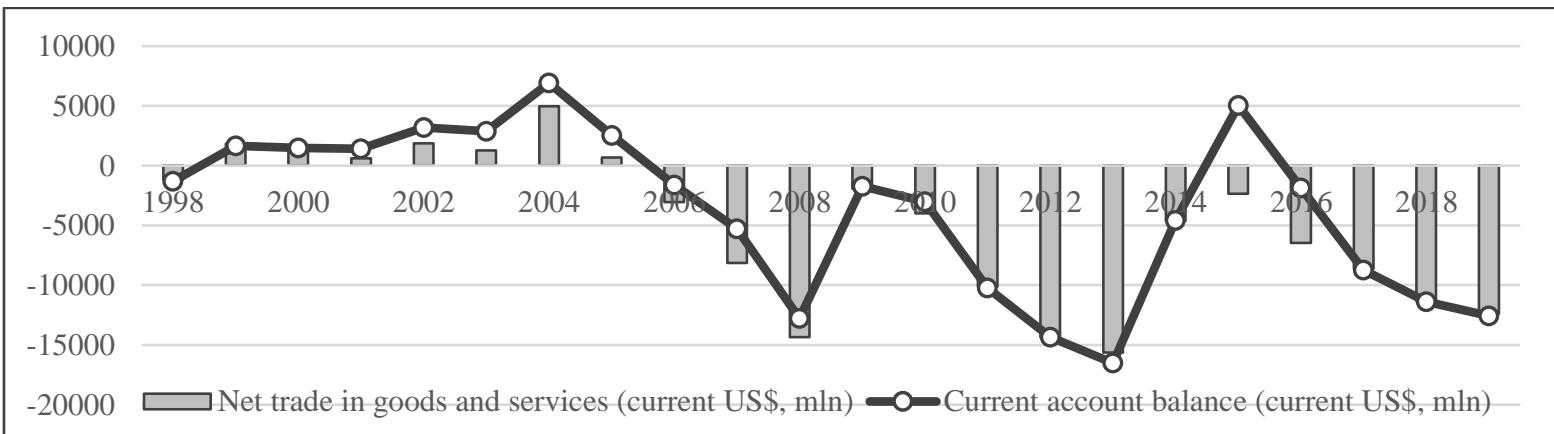

Graph 7. Net trade in goods and services and current account balance

Source: author's calculations. Data source: The State Statistics Service of Ukraine

Sharma followed the paper by Freund (2000), extending their results to 186 countries since 1960 and confirmed the main conclusion: if the current account deficit remains high for a long time (more than 5\% of GDP over five years), economic growth slows down by an average of 2,5 percentage points annually. If, however, it remains at the level of 3-4\% of GDP, it should be regarded as a warning of a slowdown in growth in the near future. Although due to the current period of deglobalization and a significant decrease in FDI, countries will find it increasingly difficult to attract foreign capital, so the critical threshold may fall from $5 \%$ to $3 \%$.

In Ukraine, the current account balance has been in deficit since 2006, except for a slight surplus in 2015. Over the last years, the deficit has been growing. Compared to 2013, these are low values, but they form a worrying trend.

Sharma, as usual, encourages paying attention to what the money is spent on. Imports of investment goods have a positive impact on economic growth. The article "Machinery, equipment, vehicles and devices" (more than a quarter of the total) has the largest share in the structure of Ukrainian imports, but it is not limited by production capacity.

In general, the Ukrainian economy is quite open, so the current operations account balance depends primarily on the dynamics of world prices for major domestic exports (corn, wheat, sunflower oil, steel, nitrogen fertilizers). Some economists are convinced that this dynamic is what determines the trend of development of the national economy, i.e., the decline of 2014-2015 would have taken place even without any known political and military events, simply because of the renewed raw material recession (Korablin, 2016).

In the Polish economy the structure of foreign trade changed significantly, despite the current account deficit during 1996-2016. Today, Polish exports consists mainly of products with a high level of value added. The inflow of FDI into the country, the location of production of multinational corporations contributed to the modernization of the economy, the formation of industry value chains, the growth of the share of the investment imports. So, improving the indicators of the balance of payments of Ukraine requires serious structural changes, diversification of exports, and complication of exported products.

Another unexpected problem for Ukraine is private remittances by migrant workers. According to the World Bank, in 2019 Ukraine became the leader in Europe in terms of its volume (World Bank, 2020). And although coronavirus-related obstacles have significantly reduced remittances in 2020, they remain a major source of currency.

According to a study by IMF, remittance helps the national economy because it improves the lives of households: increases their consumer spending, allow them to invest in human capital, finance new businesses (Chami et al., 2018). But on the other hand, empirical studies have not confirmed the significant contribution of remittances to economic growth. On the contrary, its pace is declining as dependence on funds transferred from abroad increases. Thus, countries fall into the trap of remittances with low growth rates and high emigration. 
Therefore, from this point of view, we can be sure that the intensive outflow of labor does not make Ukraine a richer country and labor depopulation threatens future economic growth. And raising wages to win the competition for Ukrainian workers with foreign companies reduces the competitiveness of domestic products on the world markets.

The ninth rule concerns the debt burden. Credit crises accompanied by increased debt are usually considered from different perspectives: who are the creditors (domestic or foreign), debtors (households, firms or the government), how large the debt burden is and how quickly it is growing. Typically, more attention is paid to public debt, the growth of which is evident during the recovery period as a result of expansionary fiscal policy.

Sharma focuses on the speed at which private debt grows. Having analyzed the data from 1960 for 150 countries, he formulates a law that claims, in his opinion, the title of the "law of economic gravity": if within five years private debt grows faster than the economy as a whole, the country is likely to experience a sharp economic decline. After the growth of private loans by more than forty percentage points, GDP growth rates are more than halved.

Similar conclusions were reached in different ways by the IMF, ECB and other international organizations. While they were not convinced by the examples of Japan in the late 1980s, Thailand and Malaysia in the late 1990s, the practice of Ireland, Greece and other countries noticeably affected by the crisis testified quite eloquently to the existence of such a pattern in the period 2004-2009. Mian et al. (2017) showed using the example of 30 countries that the accumulation of household debt slows down economic growth in the long run.

In Ukraine, mania for credits and private debt growth were observed in 2005-2007, when income growth and optimistic expectations led to an explosion of consumer and mortgage lending (Graph 8). The banking sector was booming, with people taking out massive loans. In 2005 , there was a revaluation of the hryvnia, which together with low interest rates on loans contributed to the fact that Ukrainians easily dared to borrow in foreign currency. Import grew rapidly, and the trade balance soon became negative for a long time (Graph 7). The situation was significantly complicated by the subsequent global crisis.

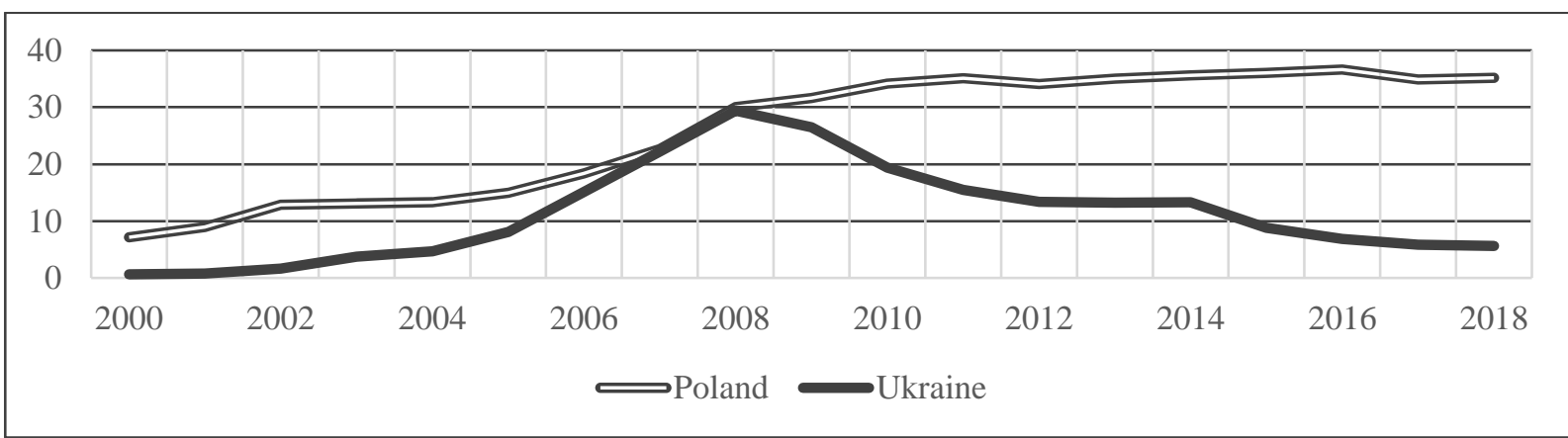

Graph 8. Household debt, loans and debt securities, Percent of GDP

Source: author's calculations. Data source: The International Monetary Fund

However, after experiencing another recession and painful banking system cleansing, the Ukrainian economy from time to time is returned to credit risks. During 2017-2019, consumer credit, according to the National Bank of Ukraine, grew faster than real GDP $(6,6 ; 15,5$ and $5,7 \%$ correspondingly vs 2,$5 ; 3,4$ and 3,2). Excessive credit growth inevitably weakens households' ability to adapt to negative shocks that do not take long to appear.

In developed countries, household debt to GDP ratio is much higher (the lion's share is usually in mortgages). In Poland, the figure has been growing steadily during 1990-2010, and has remained close to $35 \%$ for the last 10 years. In Ukraine, the contradictory dynamics of the indicator also illustrates the fact that it was no longer possible to return to the high GDP growth 
rates of 2000-2007. The situation is exacerbated by the high share of nonperforming loans $(48,4 \%$ at the beginning of 2020) which significantly complicates the banking system.

Finally, the tenth rule is easy for Ukraine to comply with. It is formulated as follows: "the global media's love is a bad sign for any economy, and its indifference is a good one". Noisy forecasts in the media about the great prospects of this or that country are in fact most often erroneous. The classic examples of countries that have been given exorbitant advances by journalists are Argentina, Japan, BRICS countries. The label "failed state" is not eternal either.

The reasons for such errors are linear thinking, habit of binary opposition, extrapolation of the latest trends. Precisely these stereotypes do not allow to accept the fact that neither growth nor decline can last forever, and the dynamics of GDP tends to "regress to the mean" (to the world average). It is quite difficult for the economy to maintain high growth rates for a long time. There are many reasons for that. One of the most popular explanations in recent times is "middle income trap". Being poor, a country can bridge the gap with developed countries through basic improvements, starting with infrastructure facilities. But as incomes grow, new and more complex industries have to be developed to maintain growth rates.

The analysis of the magazine covers unequivocally shows that the countries are ignored by the media are growing faster. Therefore, even the fact that R. Sharma leaves the development of the Ukrainian economy unattended inspires some optimism.

\section{Conclusion}

Out of ten rules considered above Ukraine corresponds only to the last one (not counting the preferred ratio between the number of people living in the capital city and the second largest city of the country). It is noteworthy that both of these rules are atypical and look less serious than the rest. Instead, Poland does not fulfill only the first rule (regarding the latter, global media has been paying close attention to the country since the time of the shock therapy). Such an explanation of the failures of the Ukrainian economy and the successes of the Polish one testifies both to the successful attempt to systematize the factors of economic growth and to the complexity and thoroughness of the Ukrainian problems.

The results of the study cannot cover the fact that some trends are global (depopulation and populism), others are typical of many developing countries (high inflation, dependence on world dynamics of export prices). However, adapted to Ukrainian conditions, these global trends are presented in their worst versions (populist-demagogues, bad billionaires, bad investments, priority development of rent-seeking industries, etc.).

The analysis allowed to address the secondary problems such as volatility of inflation, the trap of migrant remittances. This study helped to identify a common denominator of several factors, which can be perceived as a root cause. Thus, migration accelerates population decline; changing the structure of voters, increases the degree of populism in society and increases the presence of the state in the economy; finally, due to the inflow of capital in the form of remittances distorts incentives, increases the dependence of economic agents on transfers.

Some factors exacerbate the effects of others: growing income inequality and ignoring inflationary risks make it easier for populists to come to power, anti-inflationary policies make credit more expensive and reduce investment.

Therefore, Ukraine's unsatisfactory implementation of eight of the ten analyzed rules can be perceived as a kind of roadmap for the necessary changes. Demographic problems stand out. Ukraine not only does not use tax leverage to solve them (like does Poland), but also does not have accurate data on the population and migrant workers.

Education and health are not seen as drivers of economic growth for the next 5-10 years, but their inadequate levels will be the barriers to growth in the long run. Therefore, regardless 
of the current situation of the pandemic, health financing will not only contribute to the development of human capital, but also to the revival of economic growth in the future.

\section{References}

Alesina, A., \& Fuchs-Schündeln, N. (2007). Good bye Lenin (or not?): The effect of communism on people's preferences. American Economic Review, 97(4), 1507-1528. doi: 10.1257/aer.97.4.1507

Barro, R.J. (1991). Economic Growth in a Cross Section of Countries. Quarterly Journal of Economics, 106(2), 407-443. doi: 10.3386/w3120

Barro, R.J. (1995). Inflation and Economic Growth. NBER Working Paper, 5326. doi: $10.3386 /$ w5326

Billionaires. The Richest People in the World. (2020, March). Forbes. Retrieved from: https://www.forbes.com/billionaires/\#24f886a0251c

Biswas, S., \& Saha, A. K. (2014, June). Macroeconomic Determinants of Economic Growth in India: A Time Series Analysis. SOP Transaction on Economic Research. doi:10.15764/ER.2014.02006

Blanchard, O., Dell'Ariccia, G., \& Mauro, P. (2010, February). Rethinking Macroeconomic Police. IMF Staff Position Note, SPN/10/03. International Monetary Fund.

Boldeanu, F. T., \& Constantinescu, L. (2015). The main determinants affecting economic growth. Bulletin of the Transilvania University of Brasov. Economic Sciences. Series V, 8(2), 329-338.

Chami, R., Ernst, E., Fullenkamp, C., \& Oeking, A. (2018, September). Is there a remittance trap?. Finance and Development, 44-47.

Commission on Growth and Development (2008). The Growth Report: Strategies for Sustained Growth and Inclusive Development. The World Bank.

Das, M.K., \& Das, T. (2020). Determinants of economic growth in India: A time series perspective, Theoretical and Applied Economics, 2(623), 263-280.

Dornbusch, R. \& Edwards, S. (1989). The Macroeconomic Populism in Latin America. NBER Working Paper No. 2986. doi: 10.3386/w2986

Edwards, S. (2019). On Latin American populism, and its echoes around the world. Journal of Economic Perspectives, 33(4), 76-99. doi: 10.1257/jep.33.4.76

Freund, C. L. (2000). Current Account Adjustment in Industrialized Countries. International Finance Discussion Papers, No: 692. doi: 10.1016/j.jimonfin.2005.08.014

Grant D. (2019, October 13). Population decline in Central and Eastern Europe. GRI (Global Risk Insights). Retrieved from: https://globalriskinsights.com/2019/10/populationdecline-in-central-and-eastern-europe

Gordon, R. J. (2014). The Demise of U.S. Economic Growth: Restatement, Rebuttal, and Reflections. NBER Working Paper No. 19895. doi: 10.3386/w19895

Hausmann, R., Rodrik, D., \& Velasco, A. (2005). Growth diagnostics. Massachusetts, The John F. Kennedy School of Government, Harvard University.

Jha, R., \& Dang, T. N. (2012). Inflation variability and the relationship between inflation and growth. Macroeconomics and Finance in Emerging Market Economies, 5(1), 3-17. https://doi.org/10.1080/17520843.2011.608371

Korablin, S. (2016). The "lagging growth" model: economic factors and consequences for Ukraine. Economy and forecasting, 2, 74-85. https://doi.org/10.15407/eip2016.02.071

Krugman, P. R. (2012). End This Depression Now! New York: W.W. Norton \& Company. 
Kubicek, P. (1999). Ukraine. In Heenan P. \& Lamontagne M. (Eds). In The CIS Handbook (pp. 69-85). New York: Routledge Taylor \& Francis Group. https://doi.org/10.4324/9781315062136

Lewis, P., Barr, C., Clarke, S., Voce, A., Levett, C., \& Gutiérrez, P. (2019, March 6). Revealed: the rise and rise of populist rhetoric. The Guardian.

Libanova, E. (2019). Labour migration from Ukraine: Key features, drivers and impact. Economics and Sociology, 12(1), 313-328. doi:10.14254/2071-789X.2019/12-1/19

Lucas, R.E. (1988). On the mechanics of economic development. Journal of Monetary Economics, 22(1), 3-42. doi: https://doi.org/10.1016/0304-3932(88)90168-7

Mian, A., Sufi, A., Verner, E. (2017, November). Household debt and business cycles worldwide. The Quarterly Journal of Economics, 132(4), 1755-1817. https://doi.org/10.1093/qje/qjx017

National bank of Ukraine (2020). Business outlook survey. Retrieved from: https://bank.gov.ua/admin_uploads/article/BOS_2020-Q1_eng.pdf?v=4

Neanidis, K.C., Savva, C.S. (2013). Macroeconomic uncertainty, inflation and growth: Regimedependent effects in the G7. Journal of Macroeconomics, 35(1), 81-92. doi:10.1016/j.jmacro.2012.10.005

Pegkas, P. (2018, February). The effect of government debt and other determinants on economic growth: The Greek experience. Economies, 6(1), 1-19. doi:10.3390/economies6010010

Ravallion, M. \& Chen, S. (2003). Measuring pro-poor growth. Economics Letters, 78(1), 9399. https://doi.org/10.1016/S0165-1765(02)00205-7

Rodrik, D. (2018, May). Is populism necessarily bad economics?. AEA Papers and Proceedings, 108, 196-199. doi: 10.1257/pandp.20181122

Sharma, R. (2012). Breakout Nations: In Pursuit of the Next Economic Miracles. New York: W.W. Norton \& Company.

Sharma, R. (2016). The rise and falls of nations. forces of change in the post-crisis world. New York: W.W. Norton \& Company.

Sharma, R. (2020). The 10 Rules of Successful Nations. New York: W.W. Norton \& Company.

Sharma R., Kautish P. \& Kumar D.S., (2018, December). Impact of selected macroeconomic determinants on economic growth in India: An Empirical Study, Vision-The Journal of Business Perspective, 22(4), 405-415. DOI: 10.1177/0972262918823173

Simionescu, M., Ciuiu, D., Bilan, Y., \& Strielkowski, W. (2016). GDP and Net Migration in Some Eastern and South-Eastern Countries of Europe. A Panel Data and Bayesian Approach. Montenegrin Journal of Economics, 12(2), 161-175. doi:10.14254/18005845.2016/12-1/10

Simionescu, M., Bilan, Y., Mentel, G. (2017a). Economic effects of migration from Poland to the UK. Amfiteatru Economic, 19(46), 757-770.

Simionescu M., Lazányi K., Sopková G., Dobeš K., \& Balcerzak A.P. (2017b, March). Determinants of Economic Growth in V4 Countries and Romania. Journal of Competitiveness, 9(1), 103-116. DOI: 10.7441/joc.2017.01.07

Skripnichenko, M.I. (Eds.). (2018) Factors and trends of economic growth in Ukraine. Institute of Economics and Forecasting of NAS of Ukraine. Retrieved from: http://ief.org.ua/docs/mg/302.pdf

World Bank (2005, January). Economic Growth in the 1990s: Learning from a Decade of Reform. doi: 10.1596/0-8213-6043-4

World Bank (2020, April). Migration and Development Brief 32. COVID-19 Crisis through a Migration Lens.

Ukrainian Institute for the Future (2017, June 21). Demographic Crisis in Ukraine: Through 10 Years on One Employee, Two Pensioners. Retrieved from: 
https://www.uifuture.org/publications/news/22092-demograficna-kriza-v-ukraini-cerez10-rokiv-pracuucih-v-ukraini-bude-v

United Nations (2020). Population. Retrieved from: https://www.un.org/en/sections/issuesdepth/population/index.html 